\title{
Check-up and cardiovascular risk progression: is there a room for innovation?
}

\author{
Check-up e progressão do risco cardiovascular: existe espaço para inovação?
}

\author{
Raquel Dilguerian de Oliveira Conceição ${ }^{1}$, Antonio Gabriele Laurinavicius ${ }^{1}$, Nea Miwa Kashiwagi ${ }^{1}$, \\ José Antonio Maluf de Carvalho ${ }^{1}$, Carlos Alberto Garcia Oliva ${ }^{1,2}$, Raul Dias Santos Filho ${ }^{1,3}$
}

\begin{abstract}
Objective: To evaluate the impact of traditional check-up appointment on the progression of the cardiovascular risk throughout time. Methods: This retrospective cohort study included 11,126 medical records of asymptomatic executives who were evaluated between January, 2005 and October, 2008. Variables included participants' demographics characteristics, smoking habit, history of cardiovascular diseases, diabetes, dyslipidemia, total cholesterol, HDL, triglycerides, glucose, c-reactive protein, waist circumference, hepatic steatosis, Framingham score, metabolic syndrome, level of physical activity, stress, alcohol consumption, and body mass index. Results: A total of 3,150 patients was included in the final analysis. A worsening was observed in all risk factors, excepting in smoking habit, incidence of myocardial infarction or stroke and in the number of individuals classified as medium or high risk for cardiovascular events. In addition, a decrease in stress level and alcohol consumption was also seen. Conclusion: The adoption of consistent health policies by companies is imperative in order to reduce the risk factors and the future costs associated with illness and absenteeism.
\end{abstract}

Keywords: Cardiovascular diseases; Risk factors; Public health policy

\section{RESUMO}

Objetivo: Avaliar o impacto do modelo tradicional de check-up na progressão do risco cardiovascular ao longo do tempo. Métodos: Estudo coorte-retrospectivo com análise de 11.126 prontuários de executivos assintomáticos, atendidos entre janeiro de 2005 e outubro de 2008. Foram observados dados demográficos, tabagismo, doenças cardiovasculares, diabetes, dislipidemia prévios, valores de colesterol total e frações, triglicérides, glicemia, proteína C-reativa, circunferência de cintura, esteatose hepática, escore de Framingham, síndrome metabólica, nível de atividade física, estresse, consumo de álcool e índice de massa corporal. Resultados: Foram incluídos 3.150 pacientes. Houve piora de todos fatores de risco, com exceção do tabagismo, do aumento na incidência de doenças cardiovasculares e da população com risco médio ou alto para eventos cardiovasculares. Houve ainda redução na prevalência de pouco ativos, estresse e consumo de álcool. Conclusão: É prioritária a adoção de políticas de saúde por parte das empresas, para a melhora da condição de saúde e a redução dos custos advindos das doenças, além do absenteísmo a eles associados.

Descritores: Doenças cardiovasculares; Fatores de risco; Políticas públicas de saúde

\section{INTRODUCTION}

Circulatory system diseases represent the first cause of death in all regions of Brazil. This fact is mainly explained by high prevalence among population of risk factors such as smoking, overweight, physical inactivity, dyslipidemia, diabetes and hypertension. ${ }^{(1-4)}$ Control of such risk factors is, therefore, a public health priority.

In the last years, the number of executives undergoing check-up appointments has been growth in Brazil specially in large cities because of the high concentration of companies in such areas. ${ }^{(5)}$ The traditional check-up appointment is presented as an attractive strategy for systematic tracking risk factor, because it concentrates a set of tests and consultations in an single health center during a single period of time; normally from morning

\footnotetext{
'Hospital Israelita Albert Einstein, São Paulo, SP, Brazil.

2 Universidade Federal de São Paulo, São Paulo, SP, Brazil.

${ }^{3}$ Instituto do Coração (InCor), Universidade de São Paulo, São Paulo, SP, Brazil.

Corresponding author: Raquel Dilguerian de Oliveira Conceição - Avenida Brasil, 953 - Jardim América - Zip code: 01431-000 - São Paulo, SP, Brazil - Phone: (55 11) 2151-6229

E-mail: raquel.conceicao@einstein.br

Received on: June 30, 2014 - Accepted on: Jan 7, 2015

Conflict of interest: none.

DOI: 10.1590/\$1679-45082015A03216
} 
to afternoon. Despite check-up appointments constitute a promising approach to control cardiovascular risk factors, to date few evidences exist concerning efficacy of traditional check-up appointments to reduce risk of cardiovascular events.

\section{OBJECTIVE}

To evaluate the impact of traditional check-up appointment on the progression of the cardiovascular risk throughout time.

\section{METHODS}

We included 3,150 adult Brazilians who underwent two consecutive regular check-up appointments from January 2005 to October 2009 at Hospital Israelita Albert Einstein. The protocol was part of the health programs promoted and financed by private companies in the state of São Paulo. As part of the protocol, we conducted an extensive clinical and laboratory evaluations, abdominal ultrasonography and routine treadmill exercise testing. The mean interval between two check-up appointments was 24 months for men and 22 months for women. To evaluate progress of cardiovascular risk profile in the studied population within the period considered, cardiovascular risk factors were classified according to Framingham score. Our study was approved by the Ethical and Research Committee of the Hospital Israelita Albert Einstein, number 629-08 and protocol 09/1040, CAAE: 0018.0.028.000.09. A consent form was not required.

\section{Evaluation of cardiovascular risk and presence of metabolic syndrome}

Risk of cardiac death and infarction within 10 years was calculated using the Framingham score and according to sex. The participants were divided into low risk (risk $<10 \%)$, median and high risk $(>10 \%){ }^{(6)}$ Metabolic syndrome was diagnosed based on criteria of the Third Report of the Expert Panel on Detection, Evaluation, and Treatment of High Blood Cholesterol in Adults (Adult Treatment Panel III) (NCEP-ATP III). ${ }^{(7)}$

\section{Clinical variables}

Participants were asked about previous history of dyslipidemia (previous diagnosis or use of hypolipemiant), hypertension (previous diagnosis of hypertension, use of anti-hypertensive drugs or blood pressure - $\mathrm{BP}$ - measuring $\geq 140 / 90 \mathrm{mmHg}$ ), diabetes (previous use of diabetes drugs or fasting glucose $>126 \mathrm{mg} / \mathrm{dL}$ ) and smoking (consumption of at least one cigarette within the last 30 days).

Body mass index (BMI) was obtained by calculate weight/height $\left(\mathrm{kg} / \mathrm{m}^{2}\right)$ to classify individuals as eutrophics (BMI <25), overweight $(25$ to 29,9$)$ and obese $(\geq 30)$. The abdominal circumference was measured to evaluate visceral adiposity. Systolic and diastolic BP (mmhg) of each individual was taken following the American Heart Association ${ }^{(8)}$ guidelines, by using a calibrated aneroid sphygmomanometer and an adequate cuff for the arm circumference. The BP was measured three times, and the mean value obtained was considered.

We evaluated the physical exercise level (sedentary, low active, high active individuals) according to the International Physical Activity Questionnaires (IPAQ) ${ }^{(9,10)}$ criteria. Alcohol consumption was measured using the Alcohol Use Disorders Identification Test (AUDIT) questionnaire, ${ }^{(11)}$ a score $\geq 8$ was considered for moderate/ high consumption. Symptoms of stress were evaluated and classified according to Lipp's Inventory of Stress Symptoms. ${ }^{(12)}$ Application and correction of Lipp's and AUDIT questionnaires were conducted by psychologists.

\section{Laboratorial and imaging variables}

Clinical laboratory tests were done after 12 hours fasting. Total cholesterol, high-density lipoprotein cholesterol (HDL-c), triglycerides (TG) and glycemia (mg/dL) were determined by enzymatic methods in VITROS platforms (Johnson \& Johnson Clinical Diagnostics, USA). Low- density lipoprotein cholesterol (LDL-c) was calculated by Friedewald formula for TG $<400 \mathrm{mg} / \mathrm{dL}$. Impaired fasting glycemia was considered when values were between $100 \mathrm{mg} / \mathrm{dL}$ and $126 \mathrm{mg} / \mathrm{dL}$. Values of high sensitivity C-reactive protein (CRP) in $\mathrm{mg} / \mathrm{L}$ were determined by immunoturbidimetry (Dade-Boehring, USA).

All patients were submitted to abdominal ultrasonography after 6 hours minimum fasting. Fatty liver was defined by ultrasonography standard of brilliant liver with evidence of contrast between liver and renal parenchyma, using a previous described method. ${ }^{(13,14)}$ We used the Acuson XP-10 (Mountain View, USA) to analyze all tests.

\section{Intervention on cardiovascular risk factors}

After identification of cardiovascular risk factors all participants received, routinely and during check-up appointments, advices for changing lifestyle and, when indicated, they were referred to a physician in order to establish a drug therapy. Two groups of interventions 
were considered: drug intervention, evaluated by difference in use rate of hypolipemiant, anti-hypertensive and anti-diabetic drugs between the first and the second check-up appointment; and behavioral intervention, evaluated by difference in sedentary prevalence, overweight, stress and smoking between the two check-up appointments. Future global impact of these interventions on cardiovascular was estimated based on progress observed between the first and second checkup appointment, and by the Framingham score found in the studied population.

\section{Statistical analysis}

All variables were analyzed and statistics compared between groups of the first and the second checkup appointment. Association of these measures was verified in groups using $\chi^{2}$ tests. Quantitative measures were described as means (minimal; maximal). For comparisons we used $t$ test for two samples and/or the Mann-Whitney test for non-gaussian distribution variables. The $\chi^{2}$ test was used to compare categorical variables. The significance level considered was $5 \%$.

\section{RESULTS}

Table 1 show clinical and laboratory characteristics of the studied population separated by sex. This population of this study was young and approximately $60 \%$ of individuals did not exercise regularly, $65 \%$ were overweight and most of them had low estimated risk for cardiovascular disease in 10 years (85\%) according to Framingham score. However, metabolic syndrome and fatty liver were diagnosed, respectively, in almost $20 \%$ to $33 \%$ of the population. The cardiovascular risk was high in men than in women $(\mathrm{p}<0.05)$.

Figure 1 shows that number of individuals with cardiovascular risk classified as medium and high based on the Framingham score increase 38\% within the period between the first and second check-up appointment $(\mathrm{p}<0.001)$, despite the interventions done after the first evaluation. Figure 2 describes the increase of cardiovascular risk in the period within the two checkup appointments. In addition, an important highlight is that $66 \%$ of executives who were classified with high cardiovascular risk in the first check-up did not have change in this status in the second check-up.

Proportion of executives who reported use of antidiabetic agents, antihypertensive drugs and hypolipemic drugs is shown in figure 3 . In comparison with the first check-up appointment, an increase of $130 \%, 31 \%$ and $108 \%$ (respectively, $p<0.001, p<0.01$ e $p<0.001$ )
Table 1. Clinical and laboratory characteristics of the studied population in the first health evaluation separated by sex

\begin{tabular}{|c|c|c|c|}
\hline Characteristics & Male & Female & Total \\
\hline Sex, $n(\%)$ & $2.587(82.1)$ & $563(17.9)$ & $3.150(100)$ \\
\hline Age in years, mean $\pm S D$ & $44.7 \pm 8.4$ & $41.3 \pm 8.3$ & $44.1 \pm 8.5$ \\
\hline \multicolumn{4}{|l|}{ Laboratory tests, mean \pm SD } \\
\hline Total cholesterol & $198.0 \pm 36.9$ & $180.0 \pm 32.1$ & $195.0 \pm 36.7$ \\
\hline LDL-C & $121.0 \pm 33.4$ & $98.0 \pm 29.8$ & $118.0 \pm 33.7$ \\
\hline HDL-C & $48.0 \pm 11.7$ & $61.0 \pm 14.0$ & $50.0 \pm 13.1$ \\
\hline Triglycerides & $121.0 \pm 98.2$ & $82.0 \pm 42.6$ & $113.0 \pm 88.4$ \\
\hline Uric acid & $5.9 \pm 1.2$ & $3.8 \pm 1.0$ & $5.8 \pm 1.4$ \\
\hline Fasting glycemia & $91.0 \pm 16.0$ & $85.0 \pm 8.6$ & $90.0 \pm 15.3$ \\
\hline TSH & $1.9 \pm 1.5$ & $2.1 \pm 1.4$ & $2.0 \pm 1.5$ \\
\hline AA & $27.0 \pm 9.6$ & $21.0 \pm 6.1$ & $26.0 \pm 9.4$ \\
\hline GPT & $42.0 \pm 19.7$ & $29.0 \pm 10.2$ & $39.0 \pm 19.4$ \\
\hline Gama GT & $29.0 \pm 29.1$ & $17.0 \pm 11.5$ & $26.0 \pm 27.6$ \\
\hline C-reactive protein & $1.4 \pm 3.6$ & $1.3 \pm 4.1$ & $1.4 \pm 3.7$ \\
\hline Alkaline Phosphatase & $62.0 \pm 15.5$ & $57.0 \pm 14.3$ & $61.0 \pm 15.5$ \\
\hline \multicolumn{4}{|l|}{ Measurement of blood pressure, mean \pm SD } \\
\hline Systolic & $120 \pm 13.1$ & $110 \pm 13.2$ & $120 \pm 14.1$ \\
\hline Diastolic & $80 \pm 8.2$ & $70 \pm 8.1$ & $80 \pm 8.7$ \\
\hline Abdominal circumference in $\mathrm{cm}$, mean $\pm \mathrm{SD}$ & $96.0 \pm 9.6$ & $77.0 \pm 9.6$ & $93.0 \pm 11.8$ \\
\hline \multicolumn{4}{|l|}{ Medication, $n(\%)$} \\
\hline Antidiabetics & $40(1.6)$ & $1(0.2)$ & $41(1.3)$ \\
\hline Anti-hypertensive & $314(12.1)$ & $28(5.0)$ & $342(10.9)$ \\
\hline Hypolipemiant & $167(6.5)$ & $8(1.4)$ & $175(5.6)$ \\
\hline Smoking, n (\%) & $308(11.8)$ & $61(11.0)$ & $364(364)$ \\
\hline \multicolumn{4}{|l|}{ Exercise, $n(\%)$} \\
\hline Less active & $162(33.8)$ & $898(38.9)$ & $1.060(38.0)$ \\
\hline Sedentary & $121(25.3)$ & $454(19.7)$ & $575(20.6)$ \\
\hline \multicolumn{4}{|l|}{ Body mass index, $\mathrm{n}(\%)$} \\
\hline Overweight & $1.342(54.3)$ & $103(19.2)$ & $1.485(48.2)$ \\
\hline Obesity & $442(17.4)$ & $39(7.3)$ & $481(15.6)$ \\
\hline Medium and High Framingham score, $\mathrm{n}(\%)$ & $453(17.8)$ & $17(3.1)$ & $470(15.2)$ \\
\hline Fatty liver, $n(\%)$ & $287(38.4)$ & $21(10.4)$ & $308(32.5)$ \\
\hline Metabolic syndrome (ATP III) & $565(21.8)$ & $16(2.8)$ & $581(18.5)$ \\
\hline \multicolumn{4}{|l|}{ Mental health risk, $n(\%)$} \\
\hline Stress & $425(18.5)$ & $156(32.3)$ & $581(20.6)$ \\
\hline Alcohol (AUDIT>8) & $257(21.3)$ & $11(3.6)$ & $268(17.8)$ \\
\hline
\end{tabular}

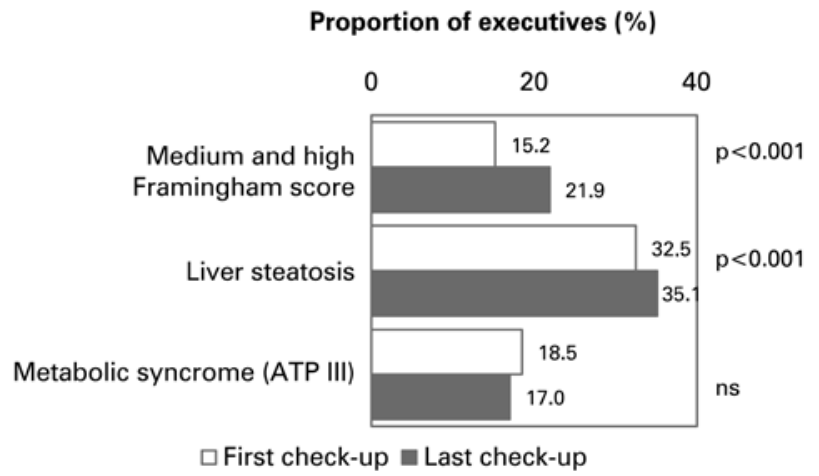

Figure 1. Progress of metabolic and cardiovascular risk 


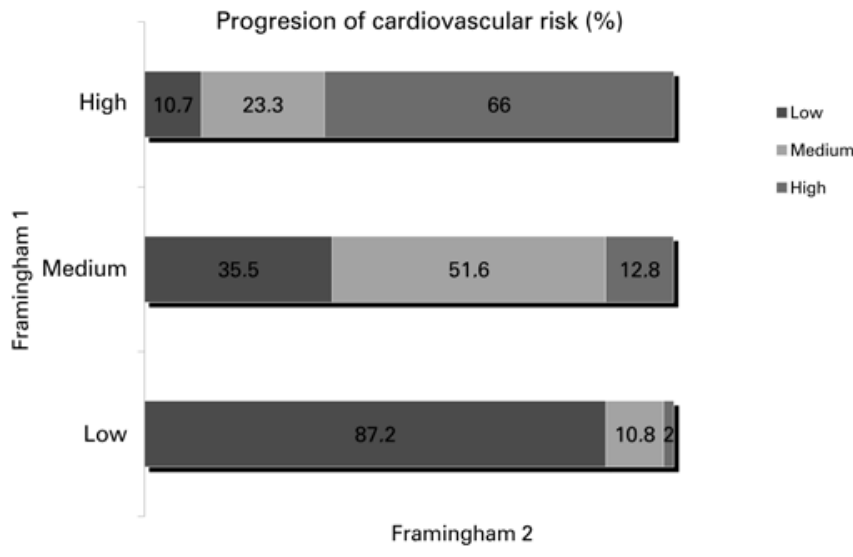

Figure 2. Progress of metabolic and cardiovascular risk based on the initial diagnosis

was seen. The markers of life style did not present changes in prevalence of obesity and overweight while prevalence of smoking and sedentary individual/ less active, which is shown in figure 4 , decreased $21 \%(\mathrm{p}<0.01)$ and $11 \%(\mathrm{p}<0.05)$, respectively. The mean ( \pm standard deviation) systolic and diastolic arteries did not change significantly between the two evaluations: $120 \pm 14.1 \mathrm{mmHg}$ and $80 \pm 8.7 \mathrm{mmHg}$ versus $120 \pm 13.6 \mathrm{mmHg}$ and $80 \pm 8.6 \mathrm{mmHg}(\mathrm{p}=$ n.s. $)$

The results seen related to mental health were reduce of stress level $(20 \%, \mathrm{p}<0.001)$ and alcohol consumption $(38 \%, \mathrm{p}<0.001)$.

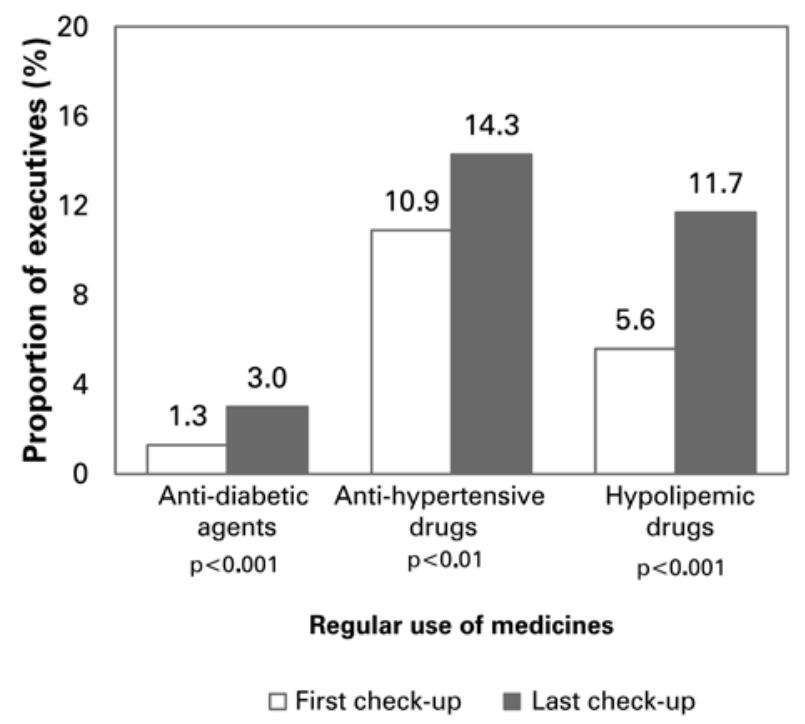

Figure 3. Use of medicines

Comparison of laboratory variables between first and second check-up appointment, showed in figure 5, had statistical difference in assessed values, $\mathrm{p}<0.001$.
In the second check-up appointment, an increase was observed in total cholesterol and LDL-c, but HDL-c decreased.

\section{Proportion of executives (\%)}

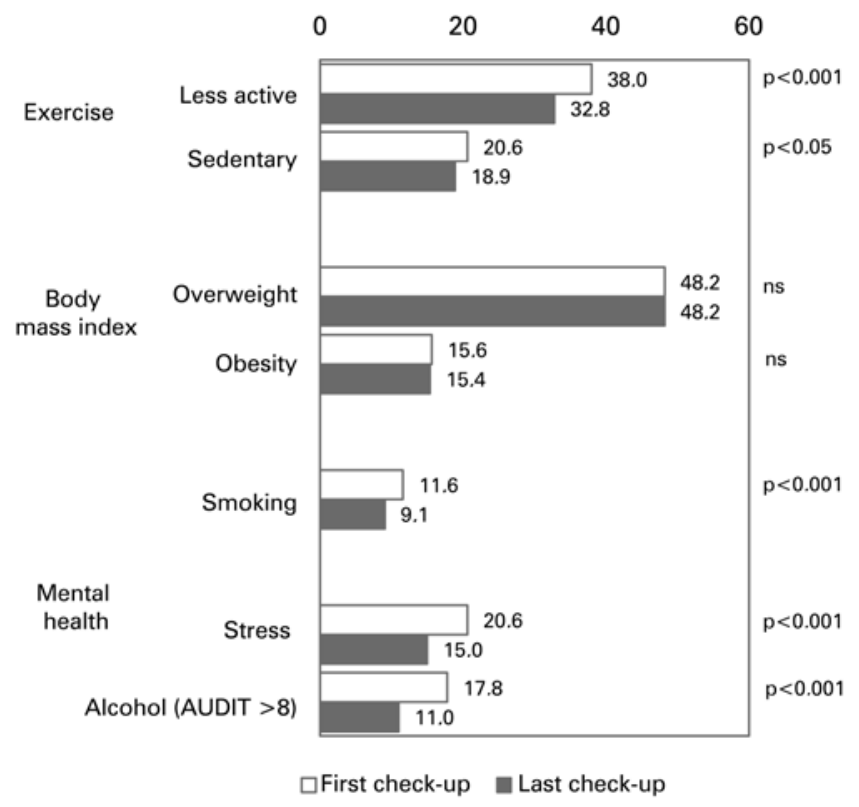

Figure 4. Progression of physical activity, body mass index and mental health status

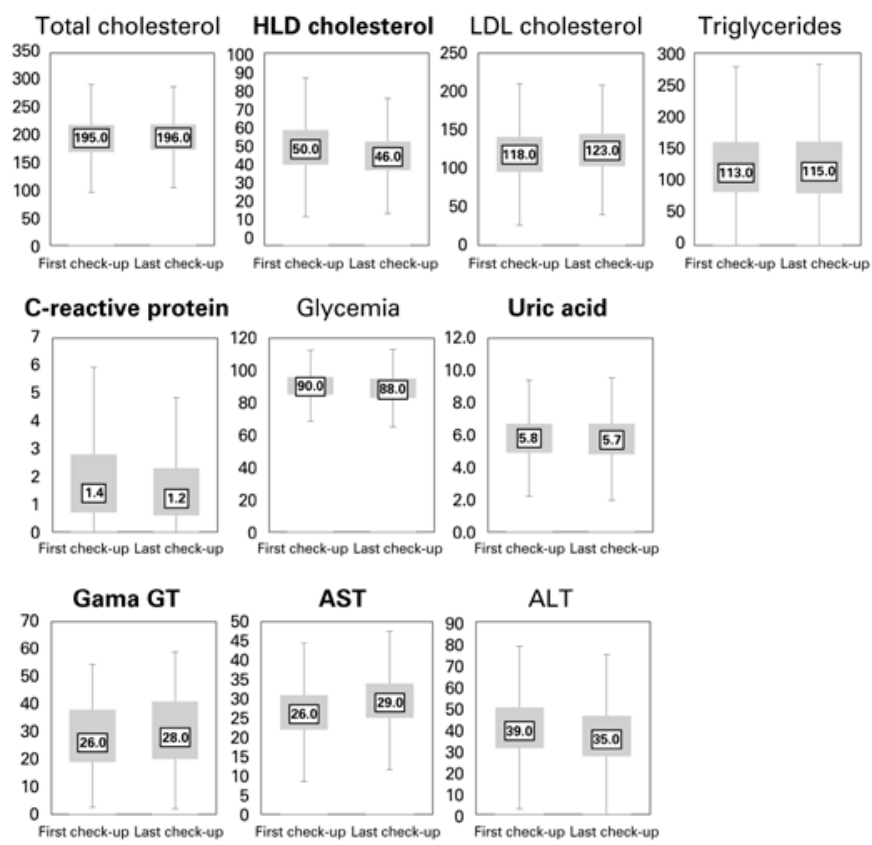

HDL: high-density lipoprotein; LDL: Low- density lipoprotein; AST; aspartate aminotransferase ALT: alanine transaminase. Figure 5. Laboratory variables

\section{DISCUSSION}

This study was the first to evaluate the impact of the traditional check-up appointment in reducing the 
prevalence of risk factors of cardiovascular disease. Our results indicated that, despite interventions done between the two check-up appointments, the proportion of executives classified with high and medium cardiovascular risk increased almost $40 \%$. This occurred despite the drop in number of smokers and increase in prescription of drugs for BP or lipids.

We assessed two set of interventions: medical prescription of hypolipemiant, anti-depressive drugs and anti-diabetic drugs; and behavioral intervention for adequacy in lifestyle related with improvement of eating habits, regular practice of exercise, adequate stress management, reduce of alcohol consumption and smoking cessation. To provide counseling to executives was efficient to increase the number of non-smokers, reduce the stress level and decrease unregulated consumption of alcohol. Although significant, the increase of exercise was moderate in absolute terms. In addition, median of cardiovascular risk increased and most of individuals in high risk remained the same. We observed a significant increase in the total of individuals using medicines in the period between the two health evaluations.

Recently, Katz et al. ${ }^{(15)}$ in a Brazilian population reported that $91 \%$ of their sample submitted to checkup and classified as high cardiovascular risk perceived themselves as low risk for cardiac events, indicating a common underestimation of cardiovascular risk perceived by individuals. The worsening of cardiovascular risk profile in the second check-up, even after prescribed recommendations according to traditional model, can be explained by the positive perception toward risk perceived by evaluated individuals. For this reason, this feeling can contribute for the maintenance of inadequate life style. ${ }^{(16,17)}$

One of the determining factors of cardiovascular risk score is age, 2 years from one to the other checkup. Our findings, however, indicate that risk increase was not only by aging, but also by the increase of total cholesterol and LDL-c, despite the increase of $130 \%$ in the use of hypolipemiant. The increase of cholesterol and reduction of HDL-c, parameterized factors in Framingham score, surely contributed to progress estimated risk. Unfortunately, our protocol did not have ways to check adherence of patients to drug therapy.

In addition to classical variables, the fatty liver prevalence is also associated to the increase of cardiovascular risk, as reported in previous studies. ${ }^{(18)}$ This prevalence, however, is closely associated to overweight, which was often found in our study and unfortunately did not improve in the studied population.
Our study findings reinforce the need to review the traditional approach of check-up appointment and to give a high emphasis to behavioral approach toward the current prescription focus. A gap exists between diagnosis after check-up and intervention needed to reduce cardiovascular risk. The adoption of strategies in lifestyle medicine can improve adherence of patient to drug therapy and optimize his/her perceptions of risk. In addition, such strategies can promote changes in patients' eating habit and exercise behavior. ${ }^{(19,20)}$

\section{Limitations of the study}

Our study has some limitations. Our prospective evaluation did not include a control group. For this reason, we could not define in which extent check-up interfered in spontaneous support to cardiovascular risk. Similarly, the type of studied population needs to be considered: relatively young and sedentary individuals who were overweight and had general, short-term, low absolute risk for cardiovascular events. The impact of a lifestyle change program in high risk population can produce different results. Although our study does not directly evaluate clinical endpoints, the risk estimation by Framingham score is widely validated in the literature and associated with prevalence of conventional risk factors.

\section{CONCLUSION}

This study showed that traditional check-up is more effective in the promotion of prescription measures than in lifestyle changes. Our results indicate the need to implement complementary strategies to the current check-up model in order to increase efficiency in cardiovascular risk control.

\section{REFERENCES}

1. Centers for Disease Control and Prevention (CDC). Chronic diseases. The power to prevent, the call to control: at a glance 2009 [Internet]. Atlanta: CDC; 2009 [cited 2014 Ago 25]. Available from: http://www.cdc.gov/chronicdisease/ resources/publications/AAG/pdf/chronic.pdf

2. Brasil. Ministério da Saúde. Secretaria de Vigilância em Saúde. Departamento de Análise de Situação de Saúde. Plano de ações estratégicas para 0 enfrentamento das doenças crônicas não transmissíveis (DCNT) no Brasil 2011-2022. Brasília (DF): Ministério da Saúde; 2011. 148 p.

3. Brasil. Ministério da Saúde. Secretaria de Vigilância em Saúde. Secretaria de Gestão Estratégica e Participativa. Vigitel Brasil 2006: vigilância de fatores de risco e proteção para doenças crônicas por inquérito telefônico. Brasília (DF): Ministério da Saúde; 2007. p. 24-77.

4. Duncan BB, Chor D, Aquino EL, Bensenor IM, Mill JG, Schmidt MI, et al Doenças crônicas não transmissíveis no Brasil: prioridade para enfrentamento e investigação. Rev Saúde Pública. 2012;46(Supl 1):126-34.

5. Brasil. Ministério da Saúde. Secretaria de Vigilância em Saúde. Departamento de Análise de Situação em Saúde. Saúde Brasil 2006: uma análise da situação de saúde no Brasil. Diferenças no perfil de mortalidade da população brasileira 
e da população beneficiária de planos de saúde. Brasília (DF): Ministério da Saúde; 2006. cap 5, p. 105-73.

6. IV Diretriz Brasileira sobre Dislipidemias e Prevenção da Aterosclerose. Departamento de Aterosclerose da Sociedade Brasileira de Cardiologia. Arq Bras Cardiol. 2007;88(Supl.1):1-19.

7. Expert Panel on Detection, Evaluation, and Treatment of High Blood Cholesterol in Adults. Executive summary of the Third Report of the National Cholesterol Education Program (NCEP) expert panel on detection, evaluation and treatment of high blood cholesterol in adults (Adult Treatment Panel III). JAMA. 2001; 285(19):2486-97.

8. Pickering TG, Hall JE, Appel LJ, Falkner BE, Graves J, Hill MN, Jones DW, Kurtz T, Sheps SG, Roccella EJ; Subcommittee of Professional and Public Education of the American Heart Association Council on High Blood Pressure Research. Recommendations for blood pressure measurement in humans and experimental animals: Part 1: blood pressure measurement in humans: a statement for professionals from the Subcommittee of Professional and Public Education of the American Heart Association Council on High Blood Pressure Research. Hypertension. 2005;45(1):142-61.

9. Matsudo S, Araújo T, Matsudo V, Andrade D, Andrade E, Oliveira LC, et al. Questionário internacional de atividade física (IPAQ): estudo de validade e reprodutibilidade no Brasil. Rev Bras Ativ Fís Saúde. 2001;6(2):5-18.

10. Craig CL, Marshall AL, Sjöström M, Bauman AE, Booth ML, Ainsworth BE, et al. International physical activity questionnaire: 12-country reliability and validity. Med Sci Sports Exerc. 2003;35(8):1381-95.

11. Saunders JB, Aasland OG, Babor TF, de la Fuente JR, Grant M. Development of the Alcohol Use Disorders Identification Test (AUDIT): WHO Collaborative Project on Early Detection of Persons with Harmful Alcohol Consumption--II. Addiction. 1993;88(6):791-804.
12. Lipp ME. Stress e suas implicações. Psicol. Estud. 1984;1 (3-4):5-19.

13. Bellentani S, Saccoccio G, Masutti F, Crocè LS, Brandi G, Sasso F, et al. Prevalence of and risk factors for hepatic steatosis in Northern Italy. Ann Intern Med. 2000;132(2):112-7.

14. Saadeh S, Younossi ZM, Remer EM, Gramlich T, Ong JP, Hurley M, et al. The utility of radiological imaging in nonalcoholic fatty liver disease. Gastroenterology. 2002;123(3):745-50.

15. Katz M, Laurinavicius AG, Franco FG, Conceicao RD, Carvalho JA, Pesaro $A E$, et al. Calculated and perceived cardiovascular risk in asymptomatic subjects submitted to a routine medical evaluation: The perception gap*. Eur J Prev Cardiol. 2014. pii: 2047487314543074.

16. Janz NK, Becker MH. The Health Belief Model: a decade later. Health Educ 0. 1984;11(1):1-47. Review.

17. Nyberg ST1, Fransson El, Heikkilä K, Alfredsson L, Casini A, Clays E, De Bacquer D, Dragano N, Erbel R, Ferrie JE, Hamer M, Jöckel KH, Kittel F, Knutsson A, Ladwig KH, Lunau T, Marmot MG, Nordin M, Rugulies R, Siegrist J, Steptoe A, Westerholm PJ, Westerlund H, Theorell T, Brunner EJ, Singh-Manoux A, Batty GD, Kivimäki M; IPD-Work Consortium. Job strain and cardiovascular disease risk factors: meta-analysis of individual-participant data from 47,000 men and women. PloS One. 2013;8(6):e67323.

18. Santos RD, Nasir K, Conceição RD, Sarwar A, Carvalho JA, Blumenthal RS Hepatic steatosis is associated with a greater prevalence of coronary artery calcification in asymptomatic men. Atherosclerosis. 2007;194(2):517-9.

19. Sagner M, Katz D, Egger G, Lianov L, Schulz KH, Braman M, et al. Lifestyle medicine potential for reversing a world of chronic disease epidemics: from cell to community. Int J Clin Pract. 2014;68(11):1289-92.

20. Dacey ML, Kennedy MA, Polak R, Philips E. Physical activity counseling in medical school education: a systematic review. Med Educ Online. 2014;19:24325. Review. 